\title{
Mesenchymal stem cell enhances chondral defects healing in horses
}

\author{
Ana Lucia Miluzzi Yamada ${ }^{1}$, Armando de Mattos Carvalho ${ }^{2}$, Andrei Moroz ${ }^{3}$, \\ Elenice Deffune ${ }^{4}$, Marcos Jun Watanabe ${ }^{1}$, Carlos Alberto Hussni ${ }^{1}$, \\ Celso Antônio Rodrigues ${ }^{1}$, Ana Liz Garcia Alves ${ }^{1 /}$ \\ ${ }^{1}$ Department of Veterinary Surgery and Anesthesiology, School of Veterinary Medicine and Animal Science (FMVZ), UNESP, Uni- \\ versidade Estadual Paulista, Botucatu, Brazil; ${ }^{\#}$ Corresponding Author: anaalves@,fmvz.unesp.br \\ ${ }^{2}$ Faculty of Veterinary Medicine, Cuiabá University, Cuiabá, Brazil \\ ${ }^{3}$ Department of Morphology, Institute of Biosciences, UNESP, Botucatu, Brazil \\ ${ }^{4}$ Blood Center, School of Medicine, UNESP, Botucatu, Brazil
}

Received 14 August 2013; revised 13 September 2013; accepted 21 September 2013

Copyright (C) 2013 Ana Lucia Miluzzi Yamada et al. This is an open access article distributed under the Creative Commons Attribution License, which permits unrestricted use, distribution, and reproduction in any medium, provided the original work is properly cited.

\section{ABSTRACT}

The purpose of this study was to evaluate the effect of intralesional Mesenchymal Stem Cells (MSC) on the treatment of experimentally induced articular chondral defects in horses, emphasizing the benefits of this application in veterinary medicine. Chondral defects were induced in the medial femoral trochlea of both hind limbs of four horses. Thirty days post induction; the horses were divided into two groups. The $G 1$ was submitted to treatment with MSC and the G2 was the control group. Clinical evaluations, synovial fluid analysis and synovial Prostaglandin $E_{2}\left(P E_{2}\right)$ assessment were performed prior to defects and fortnightly up to 120 and $\mathbf{1 5 0}$ days. Macroscopic, histopathological and histochemical evaluations were performed at the end of the experiment. The treatment with MSC reduced the intraarticular inflammatory process. The $G 1$ showed lower $\mathrm{PGE}_{2}$ concentrations in the synovial fluid and greater percentage of mononuclear cells and lower percentages of lymphocytes and neutrophils. The treatment improved the macro and microscopic aspects of repair tissue. No difference was observed in the scores of lameness between the G1 and G2. The use of MSC in the treatment of chondral defects minimized joint inflammation, as confirmed by synovial fluid analysis. The treatment resulted in an improved repair tissue, verified by macroscopic

\footnotetext{
*This study was financially supported by the FAPESP (São Paulo Research Foundation) (2008/56360-7 and 2009/06059-1).
}

examination, histochemical and histopathological analysis.

Keywords: Arthroscopy; Cartilage; Equine; Lameness; Mesenchymal Stem Cells

\section{INTRODUCTION}

Osteoarthritis is defined as a disorder of the joints considering a group of disturbances that present a common result: progressive destruction of articular hyaline cartilage [1]. In adult specimens, the articular cartilage is devoid of innervation and organization and lymphatic vessels, which results in reduced inflow of blood progenitor cells and a limited reparatory mechanism [2,3]. Thus, the repair tissue formed in extensive injuries and superficial defects is composed exclusively of fibrocartilage, which avoids the morphological and functional recovery of the tissue, resulting in the progression of osteoarthritis $[4,5]$.

Mesenchymal Stem Cells (MSC) are an important cell source that could assist in the treatment of chondral defects. They are easily harvested and own a high expansion capacity in vitro [5]. MSC are multipotent, adult cells capable of differentiating into all mesoderm tissues. They present fibroblastic morphology and should adhere to plastic, show osteogenic, adipogenic and chondrogenic differentiation and express surface markers [6,7]. The benefits resulting from the use of MSC in chondral defects and osteoarthritis, such as tropism for injured cartilage, paracrine activity, cellular differentiation and proliferation, predict good results and more effective treatments $[8-10]$. 
Satisfactory results have been achieved using stem cells in intraarticular injections, intralesional applications and within biocompatible scaffolds [11-14]. It is known that these cells are capable of secreting various bioactive molecules and are immunomodulatory and chemotactic. MSC also reduce inflammatory cell infiltrate and provide cellular support during chondral repair. However, in spite of presenting good results, MSC implantation still face failures in the application, maintenance of cellular phenotype and evidence of effectiveness, particularly in the long-term [7,8,15].

The present study observed the effects of intralesional application of MSC in fibrin glue in the treatment of chondral defects induced in horses, knowing the limited reparatory mechanism of chondral tissue, the inflammatory processes involved in osteoarthritis, the biological capabilities of this cell type and obstacles encountered in this type of treatment.

\section{MATERIALS AND METHODS}

\subsection{Surgical Procedures}

This study was approved by the Animal Experimentation Ethics Committee of the School of Veterinary Medicine and Animal Science, UNESP, Botucatu, São Paulo, Brazil, on December 17, 2008, under protocol 256/2008; which does not allow the euthanasia.

Eight patellofemoral joints of both hind limbs of four healthy horses were submitted to arthroscopic surgery [16] to produce a chondral defect. These defects were treated according to the group: Group G1 (four joints) were administered autologous implants of MSC in fibrin glue; G2 (four joints) constituted the experimental control group. The arthroscopic procedure for the induction of chondral defects was considered as day zero (D-0) of the experimental period. Then, the horses were anesthetized (general anesthesia by isoflurane inhalation) and placed in dorsal recumbency. A 10-mm-diameter defect was created in the proximal aspect of medial femoral trochlear ridge, using a motorized shaver drill and a Ferris-Smith forceps causing sufficient drilling to achieve the premeasured size. The defects were induced at sufficient depth to completely remove the articular cartilage and calcified cartilage, however without perforating the subchondral bone.

Following surgery, the horses received prophylactic antibiotics (Association of penicillin ${ }^{1}, 30.000 \mathrm{IU} / \mathrm{kg} \mathrm{q} 72$ hours IM for ten days) and anti-inflammatory medication (Phenylbutazone ${ }^{2} 4,4 \mathrm{mg} / \mathrm{kg}$ q $24 \mathrm{~h}$ IV for two days) and local curative twice daily to control postoperative pain and to prevent infections. These animals remained con-

\footnotetext{
${ }^{1}$ Antibiotic Vitalfarma, Vitalfarma Pharmaceutical Ltd., Minas Gerais, Brazil.

${ }^{2}$ Injectable Equipalazone, Phenylbutazone Marcolab, Rio de Janeiro, Brazil.
}

fined in stalls until the end of the experiment.

\subsection{Mesenchymal Stem Cells}

The MSC used in the experiment were extracted and cultured from adipose tissue harvested following an incision in a region located about $5 \mathrm{~cm}$ lateral to the midline of the tail base. A mean of $1.0 \mathrm{~g}$ of adipose tissue were collected for each horse in G1. The isolation and culture of stromal vascular fraction cells were performed according to the technique described for horses [6]. The dose used in the treatment was $10^{7}$ cells per joint. The MSC characterization was performed after the third passage (40 days on average), by flow cytometry analysis. The markers used were mouse anti-rat CD90, mouse anti-horse CD13 and mouse anti-horse CD44 and CD45. The CD13 and CD44 markers are specific for equine species, while the CD90 and CD45 markers are from different species, such that any interspecies reaction would be observed. A secondary goat anti-mouse IgGFITC marker was used. For negative control of the markers used in the samples, tests to calibrate flow cytometry were performed: cell fluorescence and fluorescence of the cells added to the secondary antibody were both read, in accordance with the technique already described [6]. MSC implantation in G1 horses was performed 30 days (D-30) following chondral defect induction (D-0) through intralesional application by arthroscopy. The acquisition of $3 \mathrm{ml}$ platelet-poor plasma, which is rich in fibrinogen, was necessary to suspend the pellet of cultivated MSC and to make the fibrin glue. Therefore was added to the compound previously prepared $10 \%$ of bovine thrombin for development of fibrin glue gel, required to seal the implant within the induced chondral defect.

\subsection{Laboratorial and Clinical Evaluations}

Collection of synovial fluid from the patellofemoral joints for analyses was performed prior to defect induction and fortnightly up to day 120 and 150 , in both groups. Analysis of synovial fluid was divided into four categories: physical, chemical and cytological examination and $\mathrm{PGE}_{2}$ assessment. For the physical examination, synovial fluid appearance and viscosity were assessed at the time of collection. For the chemical analysis, the amount of protein, fibrinogen and glucose were evaluated with reagent strips ${ }^{3}$. For the cytological examination, overall and differential counts of nucleated cells were performed, leukocytes were quantified as percentages and the concentration of synovial $\mathrm{PGE}_{2}$ was determined by enzyme immunoassay using a commercially available ELISA (Enzyme Linked Immunosorbent Assay) $\mathrm{kit}^{4}$, in

${ }^{3}$ Combur 10-Test M, Cobas, Roche, Brazil. 
accordance with the manufacturer's recommendations. Both groups were clinically evaluated at the same time that synovial fluid samples were collected. The scores of lameness in all horses of G1 and G2 were graded in scores from 0 to 5 [2] and the joints were inspected daily to verify the presence of inflammation and infection.

\subsection{Morphological Evaluations}

On D-150, both groups were submitted to macroscopic evaluation of the articular cartilage by arthroscopy. The articular surfaces of the medial femoral trochlea, the general appearance of the cartilage surface, repair tissue, cartilage erosion and fibrillation were all evaluated. At the same time, samples were collected to perform histopathological and histochemical analysis. For the histopathological analyses, sectioned samples were stained by the standard methods of Hematoxylin-Eosin (H.E.), and for the histochemical analyses the sample were stained by Picrosirius Red and Toluidine Blue. Analysis of the sections was performed under light microscope and polarizing microscope by a veterinary pathologist evaluator who was blinded to the sample groups. To evaluate tissue repair, the following aspects were considered: tissue morphology; matrix staining; structural integrity; the predominance of chondrocytes; and the presence and arrangement of collagen fibrils, considering the aspect of fibrosis.

\subsection{Statistical Methods}

For the numerical measurements was performed the "Two-Way Repeated Measures ANOVA" and the MannWhitney test. The means were compared by the Tukey test. For the measurements attributed scores, the nonparametric Kruskal-Wallis was used. When a statistically significant difference occurred, the Tukey test was used to compare median values. A value of $p<0.05$ was considered significant.

\section{RESULTS}

On D-30, the joints were distended with $\mathrm{CO}_{2}$ instead of sterile fluid, allowing the fibrin glue perfectly adhere along the borders and complete the entire place of chondral defects. The intralesional application of the treatments was performed with an $11 \mathrm{G}$ needle, model Komiyashiki. It has blunt tip and allowed adequate application of the gel compound in the gelling final stages. Thus, no obstructions of the needle were observed due to the treatment gelling. The use of $10 \%$ thrombin in the sample previously separated for treatment was adequate to achieve polymerization and adhesion of the fibrin glue

${ }^{4}$ Parameter $^{\mathrm{TM}} \mathrm{PGE}_{2}$ assay kit from R\&D Systems, Inc. Minneapolis, USA, distributed by LGC Biotecnologia, São Paulo, Brazil. with cells (Figure 1).

The mean of the initial mononuclear cells, obtained immediately following adipose tissue processing was $39.5 \times 10^{4}$ cells $/ \mathrm{mL}$. MSC following cultivation presented mean cell viability of $78 \%$ immediately prior to treatment application. A mean of $1.35 \times 10^{7}$ cells per joint were applied to G1 horses. The immunophenotypic characterization in the flow cytometry analysis revealed the mean of expression for CD13 and CD45 of 1.58\% and $0.22 \%$, respectively, which was considered negative. For CD90 and CD44, the mean expression of MSC was $98.5 \%$ and $68.5 \%$, respectively, presenting as positive expression, confirming the characterization of these cells as MSC.

In the physical and chemical exams of synovial fluid, the appearance and glucose concentration showed no significant differences between the groups and times analyzed, varying within the normal range for the species. A decrease in viscosity occurred only after the surgical procedures, in both groups. Regarding protein and fibrinogen, when the treatments were compared, no statistical difference was observed $(p>0.05)$. Protein and fibrinogen concentrations were higher only after surgery.

In the cytological examination of synovial fluid there were differences between the treated and control groups. The values found for total nucleated cells in synovial fluid are demonstrated (Table 1). Concerning cytology, the results of mononuclear cells are showed in Table 2. The percentage of neutrophils (Table 3) and lymphocytes (Table 4) were lower in G1. Regarding $\mathrm{PGE}_{2}$ quantification, lower values of $\mathrm{PGE}_{2}$ occurred in $\mathrm{G} 1$ and greater in $G 2$, but these were not statistically significant (Table 5).

No difference in lameness scores occurred between the groups, only between the times analyzed (Table 6). During inspection of the joints after surgical interventions, only mild signs of inflammation were observed, such as a slight increase in local volume and mild synovial effusion, pain during local palpation and an increase in temperature in both groups. These signs of inflammation presented remission up to day 4 or 5 following the arthroscopic procedures. No adverse clinical reactions were observed following treatment.

On D-150, G1 presented better macroscopic appearance of tissue repair compared with G2 (Figure 2). In the histopathological and immunohistochemical analyses (Figure 3), fibrocartilage formation was verified in all eight joints. The four joints from G2 only presented fibroblastic cells showing greater intensity of fibrosis. In G2, surrounding the repair tissue, in the area of transition between the newly formed tissue and the normal cartilage, the presence of dead chondrocytes and empty lacunae were observed. In the polarized images stained with Picrosirius Red, the prevalence of initial phase fibrosis 


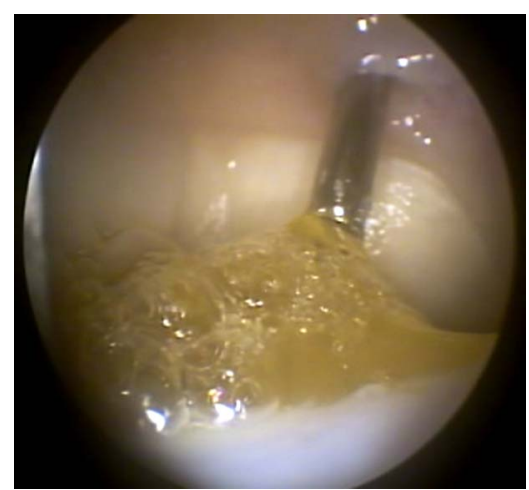

Figure 1. Arthroscopic image of application of treatment (D-30) with the MSC in fibrin glue at the injury site in G1.

Table 1. Mean total count of nucleated cells in the synovial fluid of both groups at different times during the experimental period.

\begin{tabular}{|c|c|c|c|c|c|c|c|c|c|c|}
\hline \multirow{2}{*}{ Group } & \multicolumn{9}{|c|}{ Days } & \multirow{2}{*}{$X$} \\
\hline & 0 & 15 & 30 & 45 & 60 & 75 & 90 & 120 & 150 & \\
\hline G1 & 60.0 & 568.2 & 219.8 & 550.0 & 222.5 & 161.8 & 215.0 & 190.0 & 180.7 & 263.1 \\
\hline G2 & 70.0 & 877.5 & 161.2 & 550.0 & 151.5 & 146.2 & 289.5 & 685.0 & 175.0 & 345.1 \\
\hline $\mathrm{y}$ & 65.0 & 722.9 & 190.5 & 550.0 & 187.0 & 154.0 & 252.2 & 437.5 & 177.9 & \\
\hline$x$ & B & A & $\mathrm{AB}$ & $\mathrm{AB}$ & $\mathrm{AB}$ & B & $\mathrm{AB}$ & $\mathrm{AB}$ & B & \\
\hline
\end{tabular}

Means followed by same capital letters along the row are not statistically different by the Tukey test $(p>0.05)$. Analysis of variance between treatments with repeated measurements over time (Two-way repeated measures ANOVA). Descriptive summary of the means (cells $/ \mu \mathrm{L})$. There was no statistical difference between treatments.

Table 2. Relative mean of mononuclear cells (\%) in the synovial fluid of both groups at different times during the experimental period.

\begin{tabular}{|c|c|c|c|c|c|c|c|c|c|c|}
\hline \multirow{2}{*}{ Group } & \multicolumn{9}{|c|}{ Days } & \multirow{2}{*}{$\mathrm{X}$} \\
\hline & 0 & 15 & 30 & 45 & 60 & 75 & 90 & 120 & 150 & \\
\hline G1 & 98.0 & 96.5 & 96.5 & 93.2 & 62.0 & 68.0 & 74.0 & 81.0 & 61.0 & 81.1 a \\
\hline G2 & 78.0 & 66.5 & 59.2 & 64.0 & 81.0 & 58.8 & 54.5 & 46.8 & 21.8 & $58.9 \mathrm{~b}$ \\
\hline $\mathrm{X}$ & 88.0 & 81.5 & 77.9 & 78.6 & 71.5 & 63.4 & 64.2 & 63.9 & 41.4 & \\
\hline
\end{tabular}

Table 3. Relative mean of neutrophils (\%) in the synovial fluid of both groups at different times during the experimental period.

\begin{tabular}{|c|c|c|c|c|c|c|c|c|c|c|}
\hline \multirow{2}{*}{ Group } & \multicolumn{9}{|c|}{ Days } & \multirow{2}{*}{$\mathrm{X}$} \\
\hline & 0 & 15 & 30 & 45 & 60 & 75 & 90 & 120 & 150 & \\
\hline \multirow{2}{*}{ G1 } & 0.0 & 0.0 & 0.0 & 3.0 & 9.2 & 0.8 & 3.0 & 2.0 & 1.2 & \multirow{2}{*}{$2.1 \mathrm{a}$} \\
\hline & $\mathrm{Ab}$ & $\mathrm{Ab}$ & Aa & $\mathrm{Aa}$ & Aa & Aa & $\mathrm{Aa}$ & $\mathrm{Aa}$ & $\mathrm{Aa}$ & \\
\hline \multirow{2}{*}{ G2 } & 10.0 & 14.0 & 5.0 & 2.5 & 3.0 & 7.8 & 3.8 & 10.0 & 1.2 & \multirow{2}{*}{$6.4 \mathrm{~b}$} \\
\hline & $\mathrm{Aa}$ & $\mathrm{Aa}$ & $\mathrm{Aa}$ & $\mathrm{Aa}$ & $\mathrm{Aa}$ & $\mathrm{Aa}$ & $\mathrm{Aa}$ & $\mathrm{Aa}$ & $\mathrm{Aa}$ & \\
\hline$X$ & 5.0 & 7.0 & 2.5 & 2.8 & 6.1 & 4.2 & 3.4 & 6.0 & 1.2 & \\
\hline
\end{tabular}

Table 4. Relative mean of lymphocytes (\%) in the synovial fluid of both groups at different times during the experimental period.

\begin{tabular}{ccccccccccc}
\hline & \multicolumn{10}{c}{ Days } \\
\cline { 2 - 8 } Group & $\mathbf{0}$ & $\mathbf{1 5}$ & $\mathbf{3 0}$ & $\mathbf{4 5}$ & $\mathbf{6 0}$ & $\mathbf{7 5}$ & $\mathbf{9 0}$ & $\mathbf{1 2 0}$ & $\mathbf{1 5 0}$ & \\
\hline G1 & 2.0 & 3.5 & 3.5 & 3.8 & 3.8 & 5.8 & 22.0 & 17.0 & 12.8 & $\mathbf{8 . 2} \mathbf{a}$ \\
G2 & 14.2 & 19.5 & 10.8 & 8.5 & 16.0 & 30.8 & 3.5 & 17.2 & 27.0 & $\mathbf{1 6 . 4} \mathbf{b}$ \\
X & $\mathbf{8 . 1}$ & $\mathbf{1 1 . 5}$ & $\mathbf{7 . 1}$ & $\mathbf{6 . 1}$ & $\mathbf{9 . 9}$ & $\mathbf{1 8 . 2}$ & $\mathbf{1 2 . 8}$ & $\mathbf{1 7 . 1}$ & $\mathbf{1 9 . 9}$ & \\
\hline
\end{tabular}

Means followed by same small letters down the column and capital letters along the row are not statistically different by the Tukey test $(p>0.05)$. Analysis of variance between treatments with repeated measurements over time (Two-way repeated measures ANOVA). Descriptive summary of the means in percentage.

was observed in all eight joints; however, G2 presented the highest quantity of fibrosis. In sections stained with Toluidine Blue, proteoglycan staining was moderate and irregular in the treated group, while toluidine blue staining was absent on all G2 slides.

\section{DISCUSSION}

Subchondral lesions were not used in this study. The drilling of subchondral bone induces the cell migration and passage of growth factors from the subchondral vasculature and bone marrow to the injury site, $[7,10]$ such the perforation of the subchondral bone would significantly interfere with treatment evaluation, thus it is invariably avoided.

One of the criteria for MSC characterization is their capacity of expression of surface markers CD13, CD90 and CD44, together with the absence of expression of hematopoietic lineage markers, such as CD45 [6,17]. The inverse result of CD13 marker can be explained by different methods of MSC isolation, cell culture duration, the use of monoclonal antibodies detecting different epitopes of the same protein surface or by varying degrees of sensitivity used in cytometry flow analysis $[6,17,18]$. CD13 presented no reaction in this experiment, showing incompatibility with studies involving humans $[18,19]$; however, the results obtained from the other markers confirmed the immunophenotypic MSC characterization, so a therapeutic application was possible $[6,20]$.

Concerning the laboratory analysis of synovial fluid, a reduction in viscosity following the arthroscopic procedures was expected. Joint inflammation caused by surgical aggression breaks the hyaluronate molecules, resulting in this change. The postsurgical reduction in viscosity should also be accompanied by an increase in overall cell count, which was verified during this experiment $[12,21$, 22]. Surgical aggression, even when minimally invasive, promotes different degrees of synovitis, which results in synovial effusion and the influx of proteins and fibri- 
Table 5. Mean concentration of $\mathrm{PGE}_{2}$ in the synovial fluid of both groups at different times during the experimental period.

\begin{tabular}{|c|c|c|c|c|c|c|c|c|c|c|}
\hline \multirow{2}{*}{ Group } & \multicolumn{9}{|c|}{ Days } & \multirow{2}{*}{$X$} \\
\hline & 0 & 15 & 30 & 45 & 60 & 75 & 90 & 120 & 150 & \\
\hline G1 & $568.0 \mathrm{~B}$ & $553.8 \mathrm{~B}$ & $453.9 \mathrm{~B}$ & $979.0 \mathrm{ABb}$ & $885.9 \mathrm{ABb}$ & $408.8 \mathrm{~B}$ & $1558.3 \mathrm{~A}$ & $940.8 \mathrm{ABb}$ & $364.2 \mathrm{Bb}$ & 806.3 \\
\hline G2 & $395.2 \mathrm{C}$ & $498.6 \mathrm{C}$ & $476.0 \mathrm{C}$ & $1472.7 \mathrm{ABa}$ & $1597.7 \mathrm{Aa}$ & $725.3 \mathrm{BC}$ & $855.2 \mathrm{ABCb}$ & $1405.9 \mathrm{ABa}$ & $870.9 \mathrm{ABCa}$ & 921.9 \\
\hline $\mathrm{X}$ & 481.6 & 526.2 & 465.0 & 1225.9 & 1241.8 & 567.1 & 1206.7 & 1173.4 & 617.5 & \\
\hline
\end{tabular}

Means followed by same small letters down the column and capital letters along the row are not statistically different by the Tukey test ( $\mathrm{p}>0.05$ ). Analysis of variance between treatments with repeated measurements over time (Two-way repeated measures ANOVA). Descriptive summary of the means in pg/ $\mu \mathrm{L}$. There was no statistical difference between treatments.

Table 6. Median scores for lameness and $p$ values of both groups at different times during the experimental period.

\begin{tabular}{|c|c|c|c|c|c|c|c|c|c|c|}
\hline \multirow{2}{*}{ Group } & \multicolumn{9}{|c|}{ Days } & \multirow{2}{*}{$\rho$} \\
\hline & $\mathbf{0}$ & 15 & 30 & 45 & 60 & 75 & 90 & 120 & 150 & \\
\hline G1 & $0.0 \mathrm{Ba}$ & $1.0 \mathrm{ABa}$ & $2.0 \mathrm{Aa}$ & $2.0 \mathrm{Aa}$ & $2.0 \mathrm{Aa}$ & $2.0 \mathrm{Aa}$ & $1.5 \mathrm{Aa}$ & $1.5 \mathrm{Aa}$ & $1.5 \mathrm{Aa}$ & 0.008 \\
\hline G2 & $0.0 \mathrm{Ca}$ & $1.0 \mathrm{BCa}$ & $0.8 \mathrm{BCb}$ & $1.2 \mathrm{ABb}$ & $2.0 \mathrm{Aa}$ & $2.0 \mathrm{Aa}$ & $2.0 \mathrm{Aa}$ & $1.0 \mathrm{BCa}$ & $0.5 \mathrm{BCb}$ & $<0.001$ \\
\hline$\rho$ & 1.0 & 1.0 & 0.01 & 0.13 & 1.0 & 1.0 & 0.13 & 0.13 & 0.06 & \\
\hline
\end{tabular}

Means followed by same small letters down the column and capital letters along the row are not statistically different by the Tukey test ( $\mathrm{p}>0.05$ ). Analysis of variance between treatments with repeated measurements over time (Two-way repeated measures ANOVA). Descriptive summary of the median of scores of lameness. There was no statistical difference between treatments.

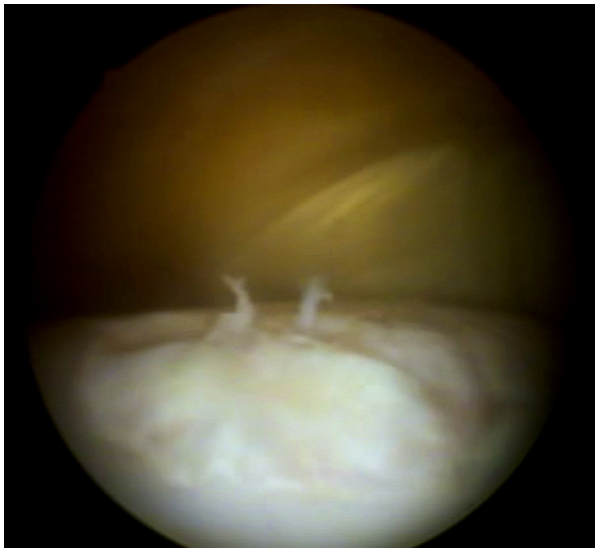

(a)

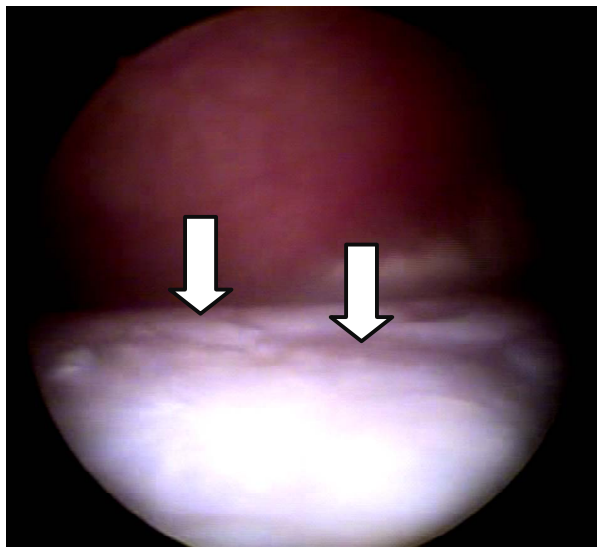

(b)

Figure 2. Arthroscopic images of the joints at D-150. Repair tissue completely filling the injury and proliferations in G1 (a). Filling failures, irregularities (arrows), minimal repair tissue formation and persistence of joint degradation in G2 (b).

nogen [2], as observed on D-15 and D-45.

Normal synovial fluid should present large quantities of mononuclear cells ( $>80 \%$ ) derived from blood monocytes, synoviocytes and tissue macrophages. The decrease in mononuclear cell counts represents varying degrees of joint inflammation [22,23], which probably occurred in the four joints from G2. Neutrophils should constitute less than $10 \%$ of the total cell count in the synovial fluid, since higher percentages are a sure indication of joint inflammation [22,23]. In this study, G2 presented higher percentages of neutrophils and lymphocytes reflecting increased joint inflammation. It is known that MSC are capable of reducing lymphocyte activation and inflammatory infiltrate, which explains the lower quantity of inflammatory cells in G1 synovial fluid $[7,8]$. The G1 presented lower concentrations of $\mathrm{PGE}_{2}$, even without the statistical differences. $\mathrm{PGE}_{2}$ is an excellent indicator of the degree of joint inflammation, because it is sensitive and detected by ELISA, and is not correlated with the nucleated cell count. Quantification of $\mathrm{PGE}_{2}$ is performed independently of leukocyte count, since it is released by synovial cells, chondrocytes and resident subchondral cells, but not neutrophils or mononuclear cells [24,25]. Administration of MSC, which are capable of inhibiting diverse inflammatory reactions and present great immunomodulatory action, explains the mild reduction in the $\mathrm{PGE}_{2}$ concentration in G1 $[8,26]$.

On D-15 and D-45, the lameness score was probably 


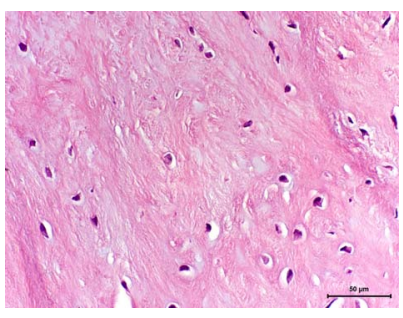

(a)

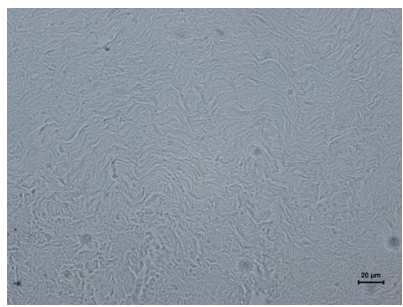

(d)

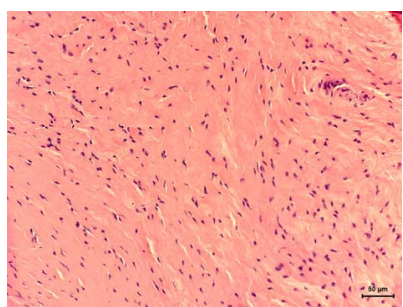

(b)

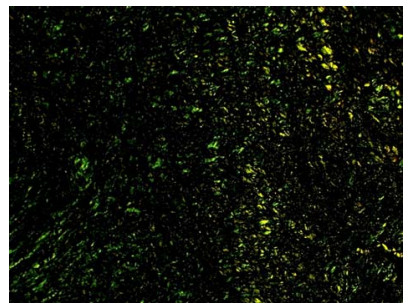

(e)

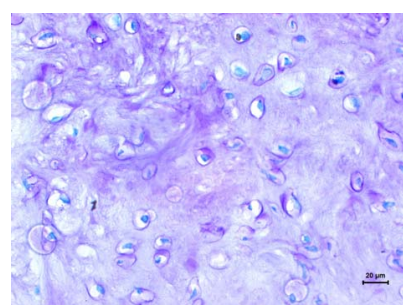

(c)

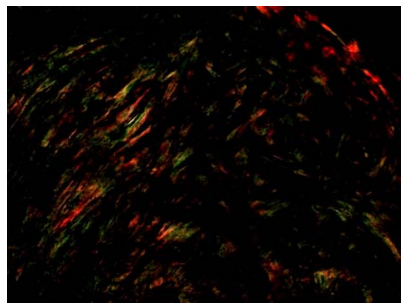

(f)

Figure 3. Photomicroscopy under natural light on D-150 (the end of experiment) of G1 (a) and G2 (b) stained by H.E., showing the formation of fibrocartilaginous tissue, with a predominance of chondrocytes in G1 (40× magnification in A and 20× magnification in B). Photomicroscopy under natural light of G1 (c) and G2 (d) stained by toluidine blue, showing irregular staining in G1 and no staining in G2 (40× magnification). Photomicroscopy under polarized light of G1 (e) and G2 (f) stained by Picrosirius Red, in which G2 presents thick fibers and predominance of yellow or red (type I collagen) and G1 presents finer fibers and predominance of green (type II collagen) (20× magnification).

not only influenced by the chondral defect created or imposed by the treatment, but also by painful stimulation of the joint capsule and synovial membrane inflammation, resulting from surgical manipulation [2,27]. The nonsignificant differences in lameness scores are contrasted by observations of a reduction in $\mathrm{PGE}_{2}$ concentrations in synovial fluid in the G1 joints $[9,28]$. This fact seems to suggest that $\mathrm{PGE}_{2}$ is not closely related to the degree of lameness or clinical manifestations of pain, but only with generalized joint inflammation [29]. We also observed that perhaps a larger number of animals for this experiment would prove most important differences in both the laboratory and clinical analysis. It was not possible to increase the number of animals due to limitations of the equine experimental model. These data are preliminary and important but more studies should be performed.

Analysis of the results obtained during macroscopic inspection of the lesions treated was in agreement with data reported in the literature, in which research involveing stem cells on the treatment of cartilage defects presented the formation of smooth white repair tissue that was apparently fibrous and well attached and completely filled, without failure of fill in the cartilage. Chondral lesions that were not submitted to treatment presented filling failure and persistent articular cartilage degradation $[12,13,15]$. Studies reported that lesions treated with stem cells present a lower rate of occurrence of erosions and fibrillations surrounding the lesion, lower rates of osteophytes, better macroscopic appearance and less ar- ticular cartilage degeneration [11,13]. The macroscopic findings for G1 joints showed a better repair tissue at six months.

The histopathological and histochemical improvement in G1 was a result of better alignment and cell proliferation and subsequent production of extracellular matrix, resulting from the chemotactic and paracrine actions of MSC that also constituted an adequate cell source $[5,7$, 30]. The increased production of fibrosis in the G2 joints, confirmed by sections stained with Picrosirius Red, prevented the samples of this group from staining with Toluidine Blue. The absence of Toluidine Blue stain in the control group was probably due to low cell density and, consequently, to lower extracellular matrix production. In spite of the irregular results regarding staining by Toluidine Blue in the treated group, a clear improvement in the response of this group was observed compared with untreated G2. Since there was no possibility of animals sacrifice, only samples harvested from the repair site, by arthroscopic, were examined.

Major obstacles to the success of cell therapy in relation to chondral defects have been reported in the literature. MSC can disperse from the implant site due to runoff and implant vehicle instability. Moreover, local inflammation may induce apoptosis because of the presence of nitric oxide, cytokines and metalloproteinases [7,31]. All these aspects are related to the findings reported for joints treated with MSC. The principal recommendations to solve these problems are the implantation of predifferentiated MSC, in scaffolds that permit 
adhesion and provide an adequate microenvironment, because they are biocompatible. Allied to this, the MSC should be administered with a cell source rich in growth factors that sustain their proliferation and differentiation $[7,10]$.

We know that fibrin glue remains on the place of the lesion for approximately one week. However, we recognize in this study the difficulty of knowing exactly how long these cells persist in the local of implant, even if it can migrate, differentiate or proliferate. Nevertheless, through our results, we can conclude that the treatment of chondral lesions with MSC reduced the degree of joint inflammation, as verified by cytological analysis of synovial fluid. Morphological evaluations [32] have shown that experimental chondral defects treated with MSC had better aspect of the repair tissue compared with the control group. The morphology of G1 was closer to normal cartilage compared with controls, but it did not reduce the lameness scores. The correct use, investigations and defined objectives make this a promising therapy in the treatment of joint injuries in horses, constituting a therapeutic possibility for structural and functional restoration of damaged articular cartilage. The use of stem cells in the treatment of chondral defects was effective, immunomodulatory and helpful in the tissue repair development.

\section{REFERENCES}

[1] Schlueter, A.E. and Orth, M.W. (2004) Equine osteoarthritis: A brief review of the disease and its causes. Equine and Comparative Exercise Physiology, 1, 221-231. http://dx.doi.org/10.1079/ECP200428

[2] Stashak, T.D. (2006) Adam's lameness in horse. 5th Edition, Roca, São Paulo.

[3] Brommer, H., Brama, P.A.J., Laasanen, M.S., Helminen, H.J., van Weeren, P.R. and Jurvelin, J.S. (2005) Functional adaptation of articular cartilage from birth to maturity under the influence of loading: A biomechanical analysis. Equine Veterinary Journal, 37, 148-154. http://dx.doi.org/10.2746/0425164054223769

[4] McIlwraith, C.W. (2005) From arthroscopy to gene therapy-30 years of looking in joints. 51th Annual Convention of the American Association of Equine Practitioners: Proceedings of the American Association of Equine Practitioners, Lexington.

[5] Coleman, C.M., Curtin, C., Barry, F.P., O'Flatharta, C. and Murphy, M. (2010) Mesenchymal stem cells and osteoarthritis: Remedy or accomplice? Human Gene Therapy, 21, 1239-1250. http://dx.doi.org/10.1089/hum.2010.138

[6] Carvalho, A.M. (2009) Autologous implant of mesenchymal stem cells adipose derived in the treatment of experimental tendinitis in equine: Clinical evaluation, ultrasonography, histopathological and immunohistochemical. Dissertation, School of Veterinary Medicine and
Animal Science, São Paulo State University, Botucatu.

[7] Vinatier, C., Mrugala, D., Jorgensen, C., Guicheux, J. and Noel, D. (2009) Cartilage engineering: A crucial combination of cells, biomaterials and biofactors. Trends in Biotechnology, 27, 307-314. http://dx.doi.org/10.1016/j.tibtech.2009.02.005

[8] Nöth, F., Steinert, A.F. and Tuan, R.S. (2008) Technology Insight: Adult mesenchymal stem cells for osteoarthritis therapy. Nature Clinical Practice Rheumatology, 4, 371380 .

[9] Frisbie, D.D., Kisiday, J.D., Kawcak, C.E., Werpy, N.M. and McIlwraith, C.W. (2009) Evaluation of adipose-derived stromal vascular fraction or bone marrow-derived mesenchymal stem cells for treatment of osteoarthritis. Journal of Orthopaedic Research, 27, 1675-1680. http://dx.doi.org/10.1002/jor.20933

[10] Fortier, L., Potter, H.G., Rickey, E.J., Schanabel, L.V., Foo, L.F., Chong, L.R., Stokol, T., Cheethan, J. and Nixon, A.J. (2010) Concentrated bone marrow aspirate improves full-thickness cartilage repair compared with microfracture in equine model. The Journal of Bone and Joint Surgery, 92, 1927-1937.

http://dx.doi.org/10.2106/JBJS.I.01284

[11] Murphy, J.M., Fink, D.J., Hunziker, E.B. and Barry, F.P. (2003) Stem cell therapy in a caprine model of osteoarthritis. Arthritis \& Rheumatism, 48, 3464-3474. http://dx.doi.org/10.1002/art.11365

[12] Wilke, M.M., Nydam, D.V. and Nixon, A.J. (2007) Enhanced early chondrogenesis in articular defect following arthroscopic mesenchymal stem cell implantation in a equine model. Journal of Orthopaedic Research, 25, 914-925. http://dx.doi.org/10.1002/jor.20382

[13] McIlwraith, C.W., Frisbie, D.D., Kisiday, J.D., Kawcak, C.E., Werpy, N.M. and Rodkey, W.G. (2010) Use of bone marrow-derived culture-expanded mesenchymal stem cells to augment healing of chondral defects treated with microfracture. Annual Convention of the American Association of Equine Practitioners: Proceedings of the American Association of Equine Practitioners, Baltimore, $27-$ 28.

[14] Carrade, D.D., Owens, D.S., Galuppo, L.D., Vidal, M.A., Ferraro, G.L., Librach, F., Buerchler, S., Friedman, M.S., Walker, N.J. and Borjesson, D.L. (2011) Clinicopathologic findings following intra-articular injection of autologous and allogeneic placentally derived equine mesenchymal stem cells in horses. Cytotherapy, 13, 419-430. http://dx.doi.org/10.3109/14653249.2010.536213

[15] Raheja, L.F., Galuppo, L.D., Bowers-Lepore, J., Dowd, J.P., Tablin, F. and Yelowley, C.E. (2011) Treatment of bilateral medial femoral condyle articular cartilage fissures in a horse using bone marrow-derived multipotent mesenchymal stromal cells. Journal of Equine Veterinary Science, 31, 147-154. http://dx.doi.org/10.1016/j.jevs.2010.12.009

[16] McIlwraith, C.W. (2005) Diagnostic and surgical arthroscopy in the horse. 3rd Edition,Mosby-Elsevier.

[17] Gimble, G.M. and Guilak, F. (2003) Adipose-derived adult stem cells: Isolation, characterization, and differentiation potential. Cytotherapy, 5, 362-369. 
http://dx.doi.org/10.1080/14653240310003026

[18] Schäffler, A. and Büchler, C. (2007) Concise review: Adipose tissue-derived stromal cells-basic and clinical implications for novel cell-based therapies. Stem Cells, 25, 818-827. http://dx.doi.org/10.1634/stemcells.2006-0589

[19] Tapp, H., Hanley, E.N.J., Patt, J.C. and Grubber, H.E. (2009) Adipose-derived stem cells: Characterization and current application in orthopaedic tissue repair. Experimental Biology and Medicine, 234, 1-9. http://dx.doi.org/10.3181/0805-MR-170

[20] Radcliffe, C.H., Flaminio, M.J.B.F. and Fortier, L.A. (2010) Temporal analysis of equine bone marrow aspirate during establishment of putative mesenchymal progenitor cell populations. Stem Cells and Development, 19, 269282. http://dx.doi.org/10.1089/scd.2009.0091

[21] Martins, E.A.N., Silva, L.C.L.C. and Baccarin, R.Y.A. (2007) Evaluation of the synovial fluid of the femuropatellar joint after experimental medial patellar desmotomy in horses. Ciência Rural, 37, 784-788. http://dx.doi.org/10.1590/S0103-84782007000300028

[22] Steel, C.M. (2008) Equine synovial fluid analysis. Veterinary Clinics of North America: Equine Practice, 24, 437-454. http://dx.doi.org/10.1016/j.cveq.2008.05.004

[23] Pozzobon, R., Brass, K.E., Fighera, R.A. and de la Corte, F. (2009) Physical, biochemical and cytological characteristics of synovial fluid with induced synovitis model in ponies. Ciência Animal Brasileira, 10, 1303-1309.

[24] May, S.A., Hooke, R.E., Peremans, K.Y. and Verschooten, F. (1994) Prostaglandin E2 in equine joint disease. Vlaams Diergeneesk Tijdschr, 63, 187-191.

[25] Bertone, A.L., Palmer, J.L. and Jones, J. (2001) Synovial fluid cytokines and eicosanoids as markers of joint disease in horse. Veterinary Surgery, 30, 528-538. http://dx.doi.org/10.1053/jvet.2001.28430

[26] Peroni, J.F. and Borjesson, D.L. (2011) Anti-inflamma- tory and immunomodulatory activities of stem cells. Veterinary Clinics of North America: Equine Practice, 27, 351-362. http://dx.doi.org/10.1016/j.cveq.2011.06.003

[27] Palmer, J.L. and Bertone, A.L. (1994) Joint structure, biochemistry and biochemical disequilibrium in synovitis and equine joint disease. Equine Veterinary Journal, 26, 263-277. http://dx.doi.org/10.1111/j.2042-3306.1994.tb04386.x

[28] Frisbie, D.D. and Smith, R.K.W. (2010) Clinical update on the use of mesenchymal stem cells in equine orthopaedics. Equine Veterinary Journal, 42, 86-89. http://dx.doi.org/10.2746/042516409X477263

[29] De Grauw, J.C., Van de Lest, C.H.A., Van Weeren, R., Brommer, H. and Brama, A.J. (2006) Arthrogenic lameness of the fetlock: Synovial fluid markers of inflammation and cartilage turnover in relation to clinical joint pain. Equine Veterinary Journal, 38, 305-311. http://dx.doi.org/10.2746/042516406777749236

[30] Khan, W.S., Johnson, D.S. and Hardingham, T.E. (2009) The potential of stem cells in the treatment of knee cartilage defects. The Knee, 1-6.

[31] Kon, E., Mutini, A., Arcangeli, E., Delcogliano, M., Filardo, G., Aldini, N.N., Pressato, D., Quarto, R., Zaffagnini, S. and Marcacci, M. (2010) Novel nanostructured scaffold for osteochondral regeneration: Pilot study in horses. Journal of Tissue Engineering and Regenerative Medicine, 4, 300-308. http://dx.doi.org/10.1002/term.243

[32] Hoemann, C., Kandel, R., Roberts, S., Saris, D.B.F., Creemers, L., Mainil Valet, P., Méthot, S., Hollander, A.P. and Buschmann, M.D. (2011) International cartilage repair society (ICRS) recommended guidelines for histological endpoints for cartilage repair studies in animal models and clinical trials. Cartilage, 2, 153-172. http://dx.doi.org/10.1177/1947603510397535 